\title{
The Evolution of Agricultural Employment in Greece
}

\author{
Paschalidis Ch. D. ${ }^{1}$, Petropoulos D. P. ${ }^{2}$, Sotiropoulos S. S. ${ }^{3}$, Paschalidis D. Ch. ${ }^{4}$ \\ Christodoulou Ch. N. ${ }^{5}$ and Papakonstantinou L. D. ${ }^{6}$
}

\begin{abstract}
Agriculture is considered one of the most important economic sectors in the European Union as it accounts for a large percentage (about 44\%) of the EU budget, but also due to the fact that a large part of its population and areas are affected by agricultural activities. In Greece, the agricultural sector is the main district of the economy with an irreplaceable and crucial role as an important employer for a large workforce, thus ensuring social cohesion and regional development. Following Greece's accession to the EU, Greek agriculture is defined by the rules of European agriculture through the Common Agricultural Policy (CAP). In general, the role of agriculture in Greece is proved by the fact that it occupies a large percentage of its land (about 30\%) and employs $82 \%$ of rural population compared to $43 \%$ of urban population. Rural population in Greece is higher than that of the rest EU member states. The agricultural sector contributes to the country's GDP directly about $4 \%$ of the gross value added of the Greek economy and despite the problems it faces, it has demonstrated relative resilience to adverse economic conditions of recent years. In the present work, statistics concerning the agricultural employment in Greece are given and the main structural problems of Greek Agriculture are mentioned. In terms of agricultural employment, the absolute number of people has decreased significantly over time. The ratio employees in agricultural sector to the total number of employees decreased from $24 \%$ in 1989 to $15.2 \%$ in 2000 and $10.6 \%$ in
\end{abstract}

\footnotetext{
${ }^{1}$ Department of Agriculture, School of Agriculture and Food Science, University of the Peloponnese, Greece.

${ }^{2}$ Department of Agriculture, School of Agriculture and Food Science, University of the Peloponnese, Greece.

${ }^{3}$ Department of Agriculture, School of Agriculture and Food Science, University of the Peloponnese, Greece.

${ }^{4}$ CGK Consulting Ltd, Maroussi, Greece.

${ }^{5}$ Hellenic Ministry of Rural Development and Food, Greece.

${ }^{6}$ Engineering Agronomist Freelancer, Greece.
}

Article Info: Received: May 10, 2021. Revised: May 20, 2021.

Published online: June 21, 2021. 
2017 but still remains significantly higher than the average of $4.4 \%$ in 2017 in the European Union. Thus, in 2017 in Greece, 453,440 thousand people worked in agriculture. In connection with the outbreak of the Coronavirus Pandemic, especially in Greece, it was found that there is a lack of labor in the countryside and that the orientation of the economy should be directed to the agricultural sector to avoid possible food shortages and most importantly that this sector may lead to the stabilization of the Greek economy.

Keywords: Agricultural holdings, People employed.

\section{Introduction}

Agriculture is considered one of the most important economic sectors of the European Union as it accounts for a large percentage (about 44\%) of the EU budget, but also because a large part of its population and areas are affected by agricultural activities, Especially for our country, Agriculture plays an irreplaceable and crucial role as an important employer for a large workforce, thus ensuring social cohesion and regional development. Greek agricultural economy and the rural world as a whole from the 19th century until today was based - and still is on the small and mainly the medium agricultural holding, which constituted, for a century and a half, the elementary cell of Greek society. After the accession of our country to the EU, Greek agriculture is determined by the rules of European agriculture through the Common Agricultural Policy (CAP). In the present work statistics concerning the agricultural employment in Greece are given and the main structural problems of the Greek agriculture are mentioned,

\section{Materials and methods}

During the drafting of the article, several scientific research methods were applied such as the study of domestic and foreign scientific literature, the regulatory framework for the research topic, the generalization of the received information, the economic and statistical analysis of the Hellenic Statistical Authority as well as the analytical and comparative method.

\section{Results and Discussion}

In general, the importance of agriculture in Greece is proved by the fact that it occupies a large percentage of its land (about 30\%) and employs $82 \%$ of rural population compared to $43 \%$ of urban population (Paschalidis. Ch. at al., 2020). The historical movement of agricultural economy and production had already passed from the phase of partial self-sufficiency to the phase of production for the market. Nowadays, it still remains in the phase of integration into a fully commercialized, national, international and global market that tends to be characterized by mechanization, prospecting for its organic connection with other sectors of the economy (processing, financial sector) within a modern "agricultural complex". To 
give an aspect of employment in agricultural production, it might be useful to first mention some data of structural characteristics of Agriculture in Greece. Structural characteristics of Greek agriculture are those factors that create the specifications and conditions for further development. These mainly consist of a very large number of small and fragmented agricultural holdings, a low percentage of irrigated agricultural land, a high percentage of economically active people employed in agriculture even in elder years (about 60\% are over 55 years old and in the busy employment of farmers (Petropoulos, D., 2020). Statistics show that there is a fragmentation of property and businesses/farms that still dominates Greek agricultural production, which is crucial for the composition and distribution of employment in this sector. While the average utilized agricultural area was 48.5 hectares in 2009. From 2009 to 2016 the number of holdings shows a decrease of 38,105 holdings or $5.3 \%$. Rural population in Greece is the highest among the states of the European Union (EU). Specifically, after a sharp decrease in the rural population in the period 1971-91, there is a decrease in the rate of population weakening in rural areas (Table 1). (Kaditi, E., Nitsi, E., 2010).

Table 1: Percentage distribution of the population of Greece based on place of residence.

\begin{tabular}{|c|c|c|}
\hline Year & Urban population \% & Rural population \% \\
\hline 1971 & 64.8 & 35.2 \\
\hline 1981 & 69.7 & 30.3 \\
\hline 1991 & 71.6 & 28.4 \\
\hline 2001 & 72.7 & 27.2 \\
\hline
\end{tabular}

Source: EL.STAT Hellenic Statistical Authority

The rural population in Greece is the highest among the States of the European Union. The emergence and consolidation of non-agricultural forms of employment since the mid-1980s has led to the stabilization and possible recovery of rural areas, although employment in the agricultural sector is directly linked to the maintenance of population in rural areas, especially in mountainous disadvantaged and rural areas. areas. (Kaditi, E. and Nitsi, E., 2010). Thus, in Greece, in 1981, before the country's accession to the E.O.C. and now in the EU, the number of people employed in the agricultural sector was 972,000. In a decade, in 2000 it was decreased by 200,000 and was 713,000, while in 2005 it reached 542,001, in 2017 453,400 and in 2019 444,600, (Figure 1). 


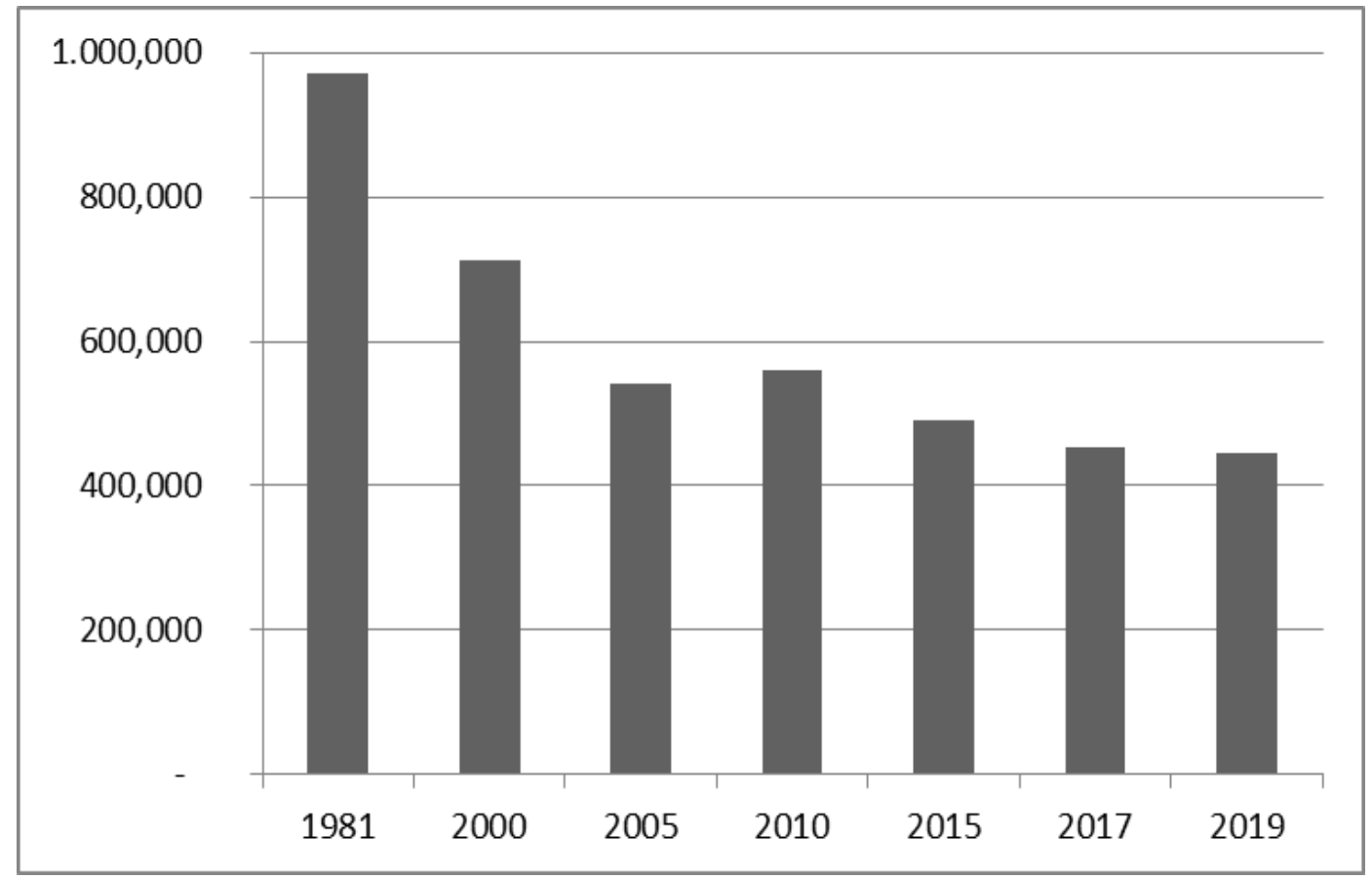

Source: EL.STAT Hellenic Statistical Authority

Figure 1: Number of employees (in thousands) in the agricultural sector

The absolute number of people employed in this field has decreased significantly over time.

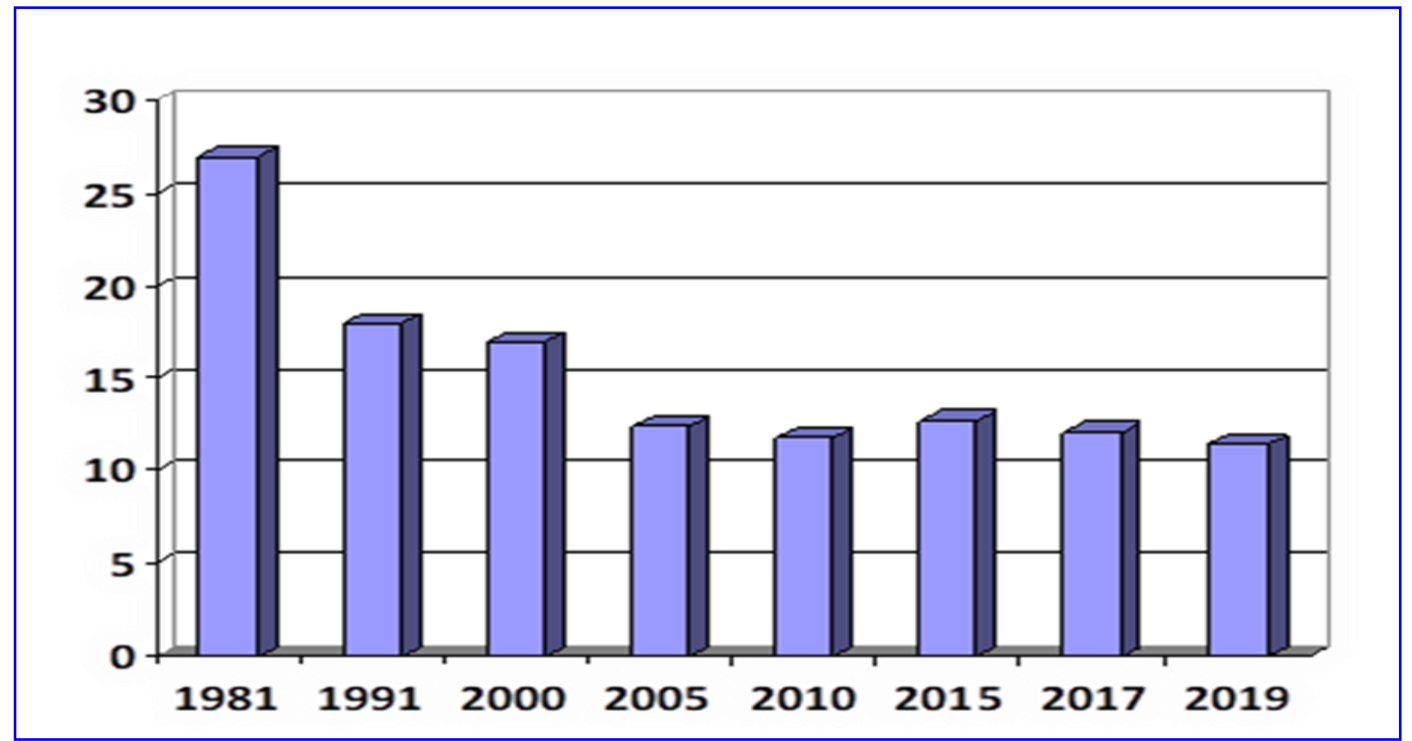

Source: EL.STAT Hellenic Statistical Authorit

Figure 2: Percentage (\%) participation of employees in the agricultural sector 
The ratio of employment in the agricultural sector to the total number of employment in the economy decreased from $27 \%$ in 1981 to $24 \%$ in 1989 , to $17 \%$ in $2000,12.4 \%$ in $2005,12.1 \%$ in 2017 and finally 11.4 in 2019 but remains significantly higher than the average of $4.4 \%$ of the European Union in 2017, (Figure 2). In terms of the ratio of employment in the agricultural sector as a whole, it is declining, but shows a downward trend after 2004. In recent decades, Greece's integration into the EU, demographic change, and globalization trends have reshaped the economic landscape. The country's human resources have been adapted accordingly, so that it can meet the needs of today's economy, which is based on services and knowledge (Kaditi, E., and Nitsi, E., 2010). Examining the percentage structure of employment by sector of economic activity, we can observe a great decline in the primary sector in recent decades. In 2019, employment in the primary sector was $11.4 \%$, while in the tertiary sector, which holds $73.2 \%$ of all employment. The secondary sector remains stable at around 15.4\% (Table 2).

Table 2: Percentage distribution of employees in Greece by sector of economic activity

\begin{tabular}{|c|c|c|c|c|}
\hline Year & $\begin{array}{c}\text { Employees in } \\
\text { the primary } \\
\text { sector \% }\end{array}$ & $\begin{array}{c}\text { Employees in } \\
\text { the secondary } \\
\text { sector \% }\end{array}$ & $\begin{array}{c}\text { Employees in } \\
\text { the tertiary } \\
\text { sector \% }\end{array}$ & $\begin{array}{c}\text { Total number of } \\
\text { employees (thousands } \\
\text { of people in the } \\
\text { primary sector) }\end{array}$ \\
\hline 1998 & 18.8 & 23.3 & 58.7 & 972 \\
\hline 1999 & 17.9 & 22.9 & 59.2 & 671 \\
\hline 2000 & 17.3 & 22.8 & 60.0 & 713 \\
\hline 2001 & 16.1 & 23.0 & 60.9 & 661 \\
\hline 2002 & 15.6 & 22.8 & 61.6 & 648 \\
\hline 2003 & 15.4 & 22.6 & 62.0 & 656 \\
\hline 2004 & 12.6 & 22.4 & 65.0 & 546 \\
\hline 2005 & 12.4 & 22.4 & 65.2 & 542 \\
\hline 2006 & 12.0 & 22.1 & 65.9 & 533 \\
\hline 2007 & 11.5 & 22.5 & 66.0 & 519 \\
\hline 2008 & 11.3 & 22.3 & 66.4 & 516 \\
\hline 2009 & 11.9 & 21.2 & 66.9 & 536 \\
\hline 2019 & 11.4 & 15.4 & 73.2 & 444 \\
\hline
\end{tabular}

Source: EL.STAT Hellenic Statistical Authority, 2020.

It is noted that from 1996 to 2007 Greece recorded quite high rates of economic growth, which, however, were not accompanied by a corresponding increase in employment. 
Table 3: Ratio (\%) of employees at Regional level (2007).

\begin{tabular}{|c|c|c|c|}
\hline Region & Percentage \% & Region & Percentage \% \\
\hline Peloponnese & 29.4 & Central Greece & 18.5 \\
\hline Eastern Macedonia-Thrace & 25.1 & Western Macedonia & 16.3 \\
\hline Thessaly & 19.9 & Central Macedonia & 11.2 \\
\hline Western Greece & 24.2 & Northen Aegean & 6.4 \\
\hline Crete & 16.9. & Southern Aegean & 15.9 \\
\hline Epirus & 19.2 & Attica & 0.7 \\
\hline Ionian Islands & 11.4 & & \\
\hline
\end{tabular}

Source: EL.STAT Hellenic Statistical Authority

At regional level in 2007, employment in the agricultural sector is not evenly distributed, (Table 3). There are regions with a high percentage of employees in the agricultural sector, such as those of the Peloponnese (29.4\%), Eastern Macedonia and Thrace $(25.1 \%)$ and Thessaly $(22.6 \%)$. In contrast, in Attica only $0.7 \%$ is employed in the agricultural sector. A significant decrease in the percentage of employment is presented in Thessaly, the Ionian Islands and Crete, while an increase in the percentage is presented in Central Greece, the South Aegean and Epirus (Kediti, E., and Nitsi, E. 2010). From 2009, when we had a decrease of 3.1\% in GDP, the employment situation has deteriorated since the outbreak of the economic crisis, confirming the dependence of the labor market on the prevailing economic environment. The results of the crisis showed that employment decreased significantly with the decline in GDP, showing that their connection is stronger during the years of crisis. In contrast, "permanent" (regular) workers are few (one in a hundred employed), but they naturally provide a large number of wages, 219 working days per year, but covering only $5.6 \%$ of total wages provided in agriculture. In general, in the course of these 7 years, from 2009 to 2016, which partly coincides with the period of economic crisis in Greece, the category of working farm owners tends to remain stable, seasonal workers are declining (remaining a very large category in all rural employment, but with the restrictions mentioned above), while the permanent or regular workers of agricultural production increase significantly in their percentage, yet remain a very small minority among the total employed in the sector. (Haritsis, A. 2018). Based on this workforce survey, Agriculture, Forestry and Fisheries account for $12.5 \%$ of total employment in the country. Farmers employers make up $12.1 \%$ of all employers in the country. The farmers self-employed $38.2 \%$ of the self-employed in total, unpaid assisted members in the agricultural sector account for $43.3 \%$ of this category in total employment, while on the contrary, the employed farmers are only $1.8 \%$ of the total number of employees in the country (Haritsis, A. 2018).

Therefore, the reduction of employment is due to the high rate of removal of selfemployed farmers from exclusive employment in agricultural production and consequently the conversion of most of them into employed or part-time employees (non-mainly farmers). Specifically, the self-employed from 746.000 Annual Work 
Unit( AWU ) in the year 1990 was reduced to570,600 AWU in 2009, showing a contraction of 175.,600 AWU within the twenty years or by one-third (23.5\%) (Tsimpoukakis E. 2012). At the same time, there is a significant decline in the employment of family members of the holder from $41.44 \%$ of total employment in 1993 to $30.12 \%$ of total in 2007.

Table 4: Distribution of agricultural employment in Greece by age

\begin{tabular}{|l|c|c|c|c|c|c|}
\hline & \multicolumn{3}{|c|}{ Percentage per year } & \multicolumn{3}{c|}{$\begin{array}{c}\text { Total number of } \\
\text { employees (thousands) }\end{array}$} \\
\hline Age categories & 1986 & 1990 & 2000 & 1986 & 1990 & 2000 \\
\hline Less than 25 & 9.2 & 9.0 & 6.9 & 94.4 & 80.0 & 46.0 \\
\hline $25-34$ & 12.0 & 11.1 & 13.4 & 123.1 & 99.0 & 90.0 \\
\hline $35-44$ & 17.5 & 17.0 & 17.7 & 179.6 & 151.0 & 119.0 \\
\hline $45-54$ & 26.7 & 25.4 & 23.6 & 273.9 & 226.0 & 158.0 \\
\hline $55-64$ & 24.9 & 29.0 & 29.0 & 255.5 & 258.0 & 195.0 \\
\hline Over 65 & 9.8 & 8.6 & 9.4 & 100.5 & 76.0 & 63.0 \\
\hline $\begin{array}{c}\text { Total agricultural } \\
\text { employment (thousands) }\end{array}$ & 100 & 100 & 100 & 1,026 & 889.0 & 671.0 \\
\hline
\end{tabular}

Source: Eurostat, Statistics, Agriculture

In addition, the reduction in the number of young people has led to significant aging of the rural population. The majority of farmers are between 45-64 years old, while about $9.4 \%$ are over $65 \%$ (Table 4). In 2005, of the approximately 542 thousand people employed in the agriculture, $55 \%$ were over 55 years old, and only $8 \%$ were under 35 years old. The future of agriculture in Greece, as in many other European countries, is threatened by an aging workforce and a lack of desire on the part of young people to work in this field. Finally, the family character of the Greek agricultural sector is shown by the structure of employment of the self-employed and employees.

Examination of the time distribution of employment by category (self-employment, employee) shows a significant increase in salaried employees with permanent and seasonal employment in agricultural production from $11.26 \%$ of total employment in 1993 to $17.83 \%$ in 2007. Of the total number of employees in the agricultural sector in 2008, 62.6\% are self-employed, $7.7 \%$ are employed, $22.4 \%$ are unpaid family members and 7.3\% are employers (ELSTAT, Labor Survey Potential, 2008. 
Table 5: Workforce structure of agricultural holdings, 2012

\begin{tabular}{|c|c|c|c|c|c|c|}
\hline & $\mathbf{2 0 0 5}$ & $\mathbf{2 0 0 6}$ & $\mathbf{2 0 0 7}$ & $\mathbf{2 0 0 8}$ & $\mathbf{2 0 0 9}$ & $\mathbf{2 0 1 0}$ \\
\hline $\begin{array}{c}\text { Self-employed } \\
\text { with staff }\end{array}$ & 37.643 & 36.661 & 40.507 & 40.875 & 46.401 & 48.518 \\
\hline $\begin{array}{c}\text { Self-employed } \\
\text { without staff }\end{array}$ & 328.114 & 325.375 & 314.073 & 321.786 & 335.636 & 349.112 \\
\hline wage earner & 35.809 & 35.183 & 34.880 & 38.477 & 48.627 & 54.049 \\
\hline $\begin{array}{c}\text { Assistant in the } \\
\text { family business }\end{array}$ & 140.434 & 136.096 & 130.264 & 115.697 & 105.896 & 103.416 \\
\hline Total & 542.001 & 533.316 & 519.725 & 516.834 & 536.559 & 555.112 \\
\hline
\end{tabular}

Source: Eurostat

There is a decrease in self-employed farmers and their family members working in agricultural production and an increase in wage labor, especially in high-profit categories.

In connection with the outbreak of the Coronavirus Pandemic, especially in Greece, it was found that there is a lack of labor in the countryside and that the orientation of the economy should be directed to the agricultural sector to avoid possible food shortages and most importantly this sector may lead to the stabilization of the Greek economy. 


\section{References}

[1] European Commission (2007).

Agriculture in the European Union, Statistics and Economic Information. DG for Agriculture and Rural Development. Brussels.

[2] European Commission - Eurostat (2010). Farm Structure-Historical ResultsSurveys from 1966/67 to 1997. Eurostat.

[3] Eurostat, Farm Structure Survey

[4] Annual Agricultural Statistical Survey for the years 2009-2020 of the Hellenic Statistical Authority.

[5] Kaditi, E. and Nitsi, E. (2010) Agricultural Sector ]in Greece, Athens, p. 266. (In Greek).

[6] Larissi, Ef. (2014). The course of the agricultural sector in Greece. Postgraduate Thesis. Aristotle University of Thessaloniki. (In Greek).

[7] Paschalidis, Ch., Sotiropoulos, S., Papakonstatinou, L., Petropoulos, D., Kavvadias, V., Paschalidis, D., and Christodoulou, Ch. (2020). Soil Resource and the Roil in Agriculture Sector of Greek Economy. Environment and Ecology Research 8(3) pp.70-75.DOI 1

[8] Paschalidis, Ch., Petropoulos, D., Sotiropoulos, S., and Papakonstatinou, L. (2018). The European Union's Common Agricultural Policy and Development of Agro-food Sector in Greece. RUDN Journal of Agronomy and Animal Industries, 13: pp. 373-382.

[9] Petropoulos, D. (2020). Introduction to Agricultural Economy Dissigma Publications p.279. (In Greek).

[10] Tsimpoukakis, H. (2012). The Evolution of Agricultural Production in Greece. KOMEP T. 6 (In Greek).

[11] Haritsis, A. (2018). Work and Employment in Greece Annual Report of the National Institute of Labor and Human (In Greek). 